2. DE VRIES, B. 2007. Saskatchewan Rare and Endangered Lichens. Preliminary Lichen Ranking List. Unpublished.

3. GOULD, J. 2000. Alberta Natural Heritage Information Centre Preliminary Lichen Tracking List. Alberta Environment, Edmonton, AB.

4. LOOMAN, J. 1962. Some lichens of Saskatchewan. The Bryologist 65: 294-304.

5. LOOMAN, J. 1964a. Ecology of lichens and bryophyte communities in Saskatchewan. Ecology 45(3): 481-491.

6. LOOMAN, J. 1964b. The distribution of some lichen communities in the prairie provinces and adjacent parts of the Great Plains. The Bryologist $67(2): 209-224$

7. LOOMAN, J. 1969. Squamarina crassa in Saskatchewan. The Bryologist 72(3): 412-413.

8. NASH, T.H. III, B.D. RYAN, C. GRIES, and F. BUNGARTZ 2002. Lichen Flora of the Greater Sonoran Desert region. Volume I (The Pyrenolichens and Most of the Squamulose and Macro Lichens). Lichens Unlimited, Arizona State University, Tempe, AZ, USA.

9. POLUNIN, N. 1960. Introduction to Plant Geography. McGraw Hill Book Company, New York, Toronto, London.

\title{
BIOLOGY OF DOWNY ARROW-WOOD (VIBURNUM RAFINESQUIANUM)
}

TOM REAUME, 212 Sherburn Street, Winnipeg, MB, R3G 2K6; E-mail: <tj333reaume@yahoo.com>

\section{Introduction}

Downy Arrow-wood (Viburnum rafinesquianum [Schultes]) is a member of the honeysuckle family Caprifoliaceae. A rhizomatous, medium-sized native, this deciduous shrub is found in the eastern half of North America. It grows singly or in thickets along streams, in open woodlands, and on wooded rocky hillsides.

Ink drawings were made from plants in the field and from fresh specimens. The original drawings were donated to the Hunt Institute for Botanical Documentation, Pittsburgh, PA.

\section{Study}

This study took place in late 2005 and throughout 2006 in Winnipeg, Manitoba. It was initiated and funded by the author. The study area at $49^{\circ}$ 52.399; $97^{\circ} 14.073$ and 235 m elevation was an open Bur Oak (Quercus macrocarpa) woods in Assiniboine Park. Bur Oak, the only oak in Manitoba, had an average diameter at breast height (dbh) of 18 (range: 232) $\mathrm{cm}(n=122)$. In three 96 by $2 \mathrm{~m}$ random transects, 43 oak trees each occupied an area of $13 \mathrm{~m}^{2}$.

Other vascular plants in the study area included Mountain Maple (Acer spicatum), Saskatoon Service-berry (Amelanchier alnifolia), Red-osier Dogwood (Cornus alba), American Hazelnut (Corylus americana), hawthorn (Crataegus spp.), Green Ash (Fraxinus pennsylvanica), Aspen Poplar (Populus tremuloides), European Buckthorn (Rhamnus cathartica), goldenrod (Solidago spp.), Poison Ivy (Toxicodendron rydbergii), and Nannyberry (Viburnum lentago).

\section{Morphology}

Plants were erect, with opposite branches and leaves. Before the first branches developed, young vegetative plants up to ca. $30 \mathrm{~cm}$ tall had two to several pairs of opposite, spreading leaves along the stem. Tall reproductive plants were somewhat leaning or nodding. Plant height and 
width averaged $107(12-217) \mathrm{cm}$ and $51(7-140) \mathrm{cm}(n=78)$, respectively. Stem basal width (ca. $5 \mathrm{~cm}$ above ground) averaged $8(1.3-17.2) \mathrm{mm}$. In thickets, the mean nearest neighbor distance was $21(1-170) \mathrm{cm}$, with $48 \%$ of the plants within $1-10 \mathrm{~cm}$ of each other. The stem made a $90^{\circ}$ bend $5-$ $10 \mathrm{~cm}$ below ground and continued horizontally as a rhizome. The smooth brown rhizomes were $2-15 \mathrm{~mm}$ thick with fine branching roots $5-20 \mathrm{~cm}$ long.

\section{Leaves}

On 27 April, young hairy leaves within buds were covered with translucent, round, short, stipate glands on both sides and along the veins. Hairs were eglandular.

Mature leaf blades were simple, pointed, toothed, and spreading to drooping (Fig. 1). Dorsally (below), the blades were very hairy with white, ascending, curved to straight hairs $0.2-1.2 \mathrm{~mm}$ long generally pointing toward the apex. Most hairs were simple, although some were two- or three-branched. The blade margins were ciliate. Upper surface hairs were simple, widely scattered and $0.2-0.4$ $\mathrm{mm}$ long. Hairs were more numerous on the blade near the petiole. The soft hairs gave a downy feel; hence the name.

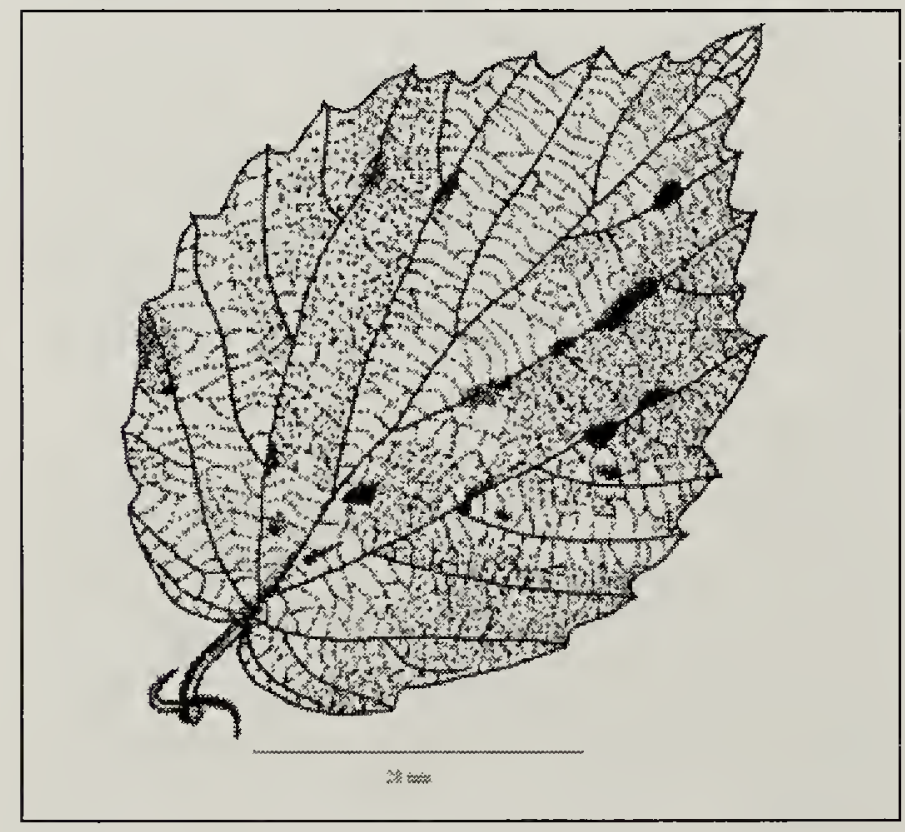

Figure 1. Leaf (ventral side) of Downy Arrow-wood, 21 September
Dorsally, the midrib (midway) was ca. $0.4 \mathrm{~mm}$ thick with the main side veins ca. $0.2 \mathrm{~mm}$ thick. The reddish purple blotches that develop in late summer along the midrib and veins distinguish this species.

New reproductive twigs usually had two $(63 \%)$, one $(35 \%)$, or three $(2 \%)$ pairs of leaves $(n=46)$. On 8 September, the internodal distance between paired leaves (top pair to the next lower pair) on new reproductive and vegetative twigs averaged 4.2 $(1.3-7.8) \mathrm{cm}(\mathrm{n}=65)$. Fully developed leaves in August through early October averaged $6(2.6-10.7) \mathrm{cm}$ long by 3.8 $(1.8-7) \mathrm{cm}$ wide for a length to width ratio of 1.6 to $1(n=167)$. The average width was $64 \%(37-102 \%)$ of the length. A leaf blade was $0.1 \mathrm{~mm}$ thick.

On 25 July, most blades were green but some had reddish purple blotches; by 4 August, some leaves were turning reddish; on 3 September, most blades were reddish and some leaves had dropped; by 22 September, some blades had their edges curled up and inward on the ventral side prior to falling; and by 14 October, over $95 \%$ of the leaves had fallen; a few overwintered on the shrubs.

Blades were rarely entire; most had 3-11 pointed teeth along each margin. Teeth were $7(5.8-11) \mathrm{mm}$ long in September $(n=255)$. Teeth became indistinct and blunt near the base of the blade.

Petioles were about $8(3-14) \mathrm{mm}$ long $(n=111)$, which was about $14 \%$ of the average length of a leaf blade. Petioles were hairy, $1-1.4 \mathrm{~mm}$ wide with a ventral groove ca. $0.3 \mathrm{~mm}$ deep that turned red by early August. The round dorsal side, bluntly ridged, remained green. On 3 August, the mean upper angle between opposite reddish petioles was $84^{\circ}\left(40-140^{\circ}\right.$; $\mathrm{n}=25$ ). 
Stipules (Fig. 2) were paired, curved, green with a reddish tip, $3.4(1-13)$ $\mathrm{mm}$ long by $0.3-1 \mathrm{~mm}$ wide (not including hairs) by ca. $0.2 \mathrm{~mm}$ thick $(n=148)$, attached 0.9-2.6 $(-5.5) \mathrm{mm}$ from the base of the petiole along the edge of the ventral (upper) groove. They were persistent, entire, flattened, pointed, wider above and tapered to their base. Hairs were mostly simple, $<1 \mathrm{~mm}$ long, and rarely two- or threebranched. Stipules in early May were covered with stipitate, round, light yellowish green glands. One stipule 1-7 mm long developed below the normal pair and the base of the petiole $23 \%$ of the time. Rarely, four stipules appeared on a petiole. In early September, stipules were tan, erect, straight, and often parallel to each other.

\section{Reproductive Twigs}

On 12 May, new green to reddishgreen reproductive twigs were mostly hairless or with some V-branched hairs, eglandular to slightly stipitateglandular and with six or five low blunt

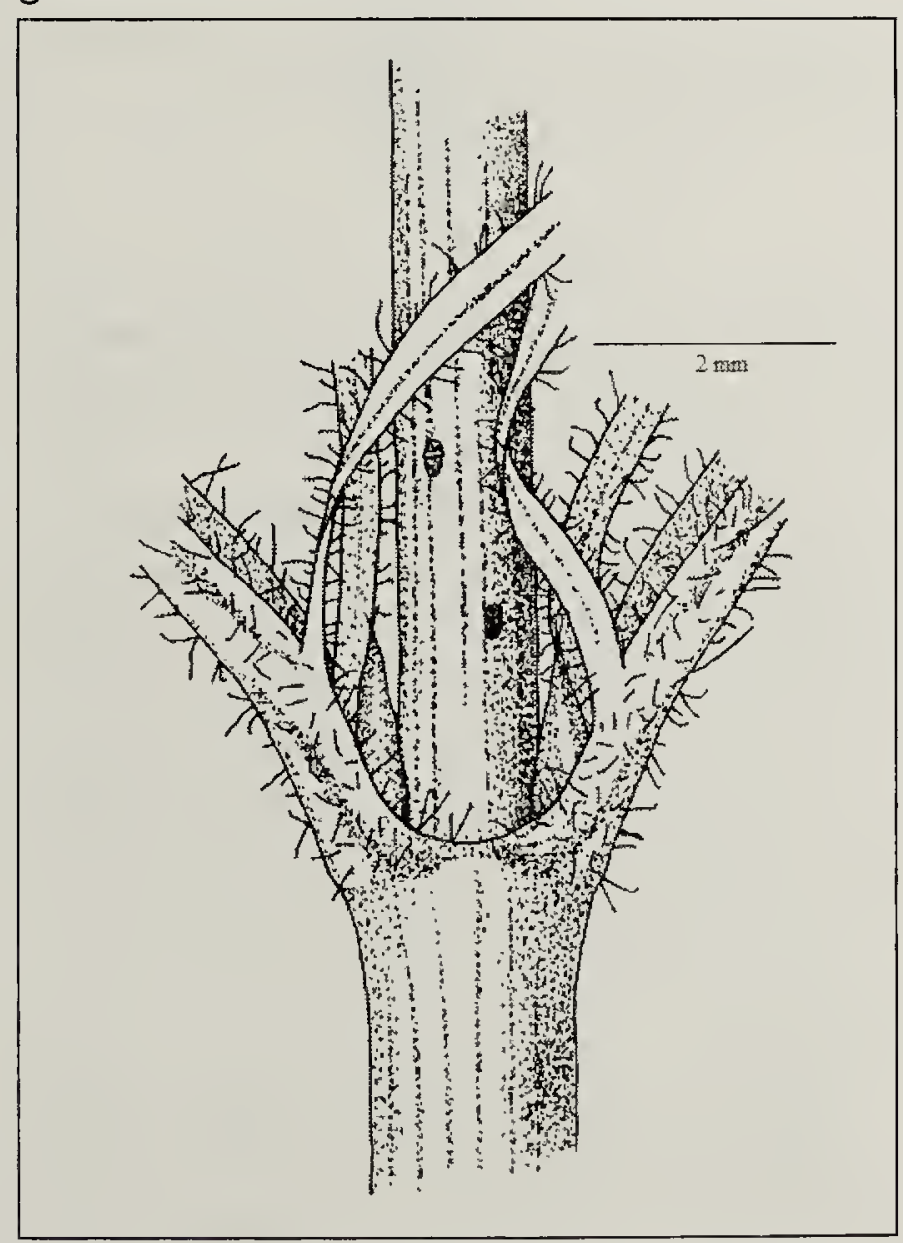

Figure 2. Bases of two petioles and four stipules, 2 June ridges. Twig length was measured from the base of the bud from which it sprang to the top of the buds/flowers on several shrubs. On 1 June, with flowering underway, the twig length averaged $10(5.4-21) \mathrm{cm}$ by $1.1-2 \mathrm{~mm}$ wide, with $80 \%$ of the twigs $5.4-12.2$ $\mathrm{cm}$ long $(\mathrm{n}=47)$.

On 19 September, the wide upper angle between opposite twigs averaged $85^{\circ} \quad\left(48-127^{\circ} ; n=42\right)$. Opposite branches or twigs often had one of the pair longer than the other.

Lenticels were ca. $0.4 \mathrm{~mm}$ long by ca. $0.3 \mathrm{~mm}$ wide, slightly raised, reddish-tan, mostly oval with their long axis parallel to that of the twig.

Older twigs, 1 year or more, were oval, brownish-gray, smooth, hairless, and 1.2-2 $\mathrm{mm}$ thick. On 14 October, leafless plants of seven selected shrubs averaging 151 (92-179) cm tall had an internodal distance between paired branches along the main stem from the base averaging $7.3(2.5-31)$ $\mathrm{cm}(\mathrm{n}=112)$. For selected plants, 183 $(145-240) \mathrm{cm}$ tall $(n=25)$, the height from the ground to the first branch or paired branches was $75(33-130) \mathrm{cm}$ or $41 \%$ of a shrub's height.

\section{Terminal and Axillary Buds}

Reddish-brown terminal buds (Fig. 3 ), which form during the summer and overwinter, have two pairs of outer scales and two pairs of inner bracts. In early March, the buds were 4-5.2 $\mathrm{mm}$ long by $2-2.2 \mathrm{~mm}$ wide. Their lowest pair of outer, opposite, stiff scales was $2-3.3 \mathrm{~mm}$ long (including a $0.3-1.3 \mathrm{~mm}$ long awn) by ca. $3 \mathrm{~mm}$ wide (flattened) and wrapped around the base of a bud. Margins were ciliate with white hairs. The upper pair of outer scales was $4-5.2 \mathrm{~mm}$ long by $4.5-5$ $\mathrm{mm}$ wide (flattened), thin, easily torn, reddish-brown, awnless, and with ciliate margins. 


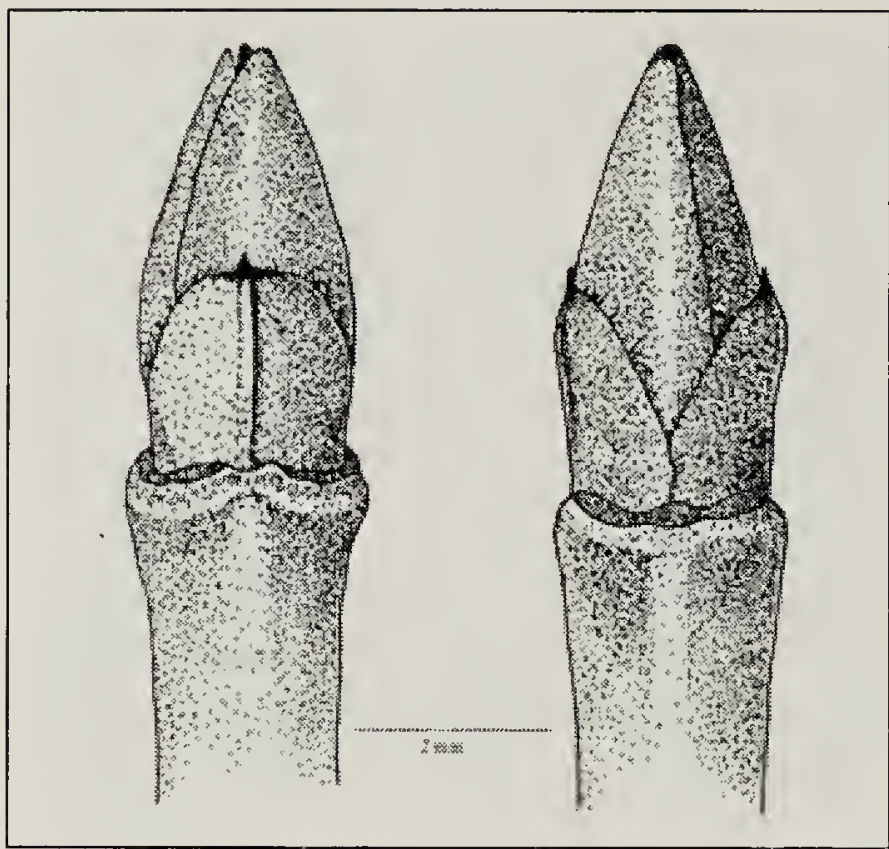

Figure 3. Terminal bud on short side twig, January

After a terminal bud expanded in April and eventually opened, two pairs of inner bracts became evident. The first exserted pair had a reddish brown blunt tip and was $6-10 \mathrm{~mm}$ long by $5-$ $7 \mathrm{~mm}$ wide. On the outside (dorsal side) of the bract were white appressed hairs; inside (ventrally), the bract was hairless. Margins were white, hyaline, and ciliate. The top inner pair of bracts was $15-20 \mathrm{~mm}$ long by $5-7 \mathrm{~mm}$ wide on 20 April and slightly exserted. Their dorsal side was very hairy and stipitate-glandular; the ventral side was hairless. Shallow blunt apical teeth contrasted with the truncate and untoothed base. On 3 September, buds in axils of leaf petioles were 3-4 $\mathrm{mm}$ long by ca. 2 $\mathrm{mm}$ wide by ca. $1.5 \mathrm{~mm}$ thick with two outer pairs of ciliate scales.

\section{Inflorescence}

Peduncles were 5- or 6-sided, green, rarely absent, $2.8(0.5-5) \mathrm{cm}$ long by $1.1(0.8-1.6) \mathrm{mm}$ thick, densely stipitate-glandular in the apical half. The dark brown to blackish glands persisted. By mid-August, the peduncles were mostly reddish brown.

Subtending bracts of outer rays were 4-7.5 $\mathrm{mm}$ long by ca. $1 \mathrm{~mm}$ wide and fall quite early. Usually seven (4-7), pink, oval rays averaging $8(2-20) \mathrm{mm}$ long $(n=29)$ ascended from the apex of the peduncle. Central rays had $4-20$ flowers and outer rays each had 2-11 flowers. The mean number of flowers per ray was $6(2-20 ; n=23)$.

Flower buds (Fig. 4a) on 12 May were in tight green clusters (cymes) ca. $15 \mathrm{~mm}$ long by ca. $10 \mathrm{~mm}$ wide (Fig. 4b). On 1 June, the number of flowers/buds per inflorescence averaged 47 (13-122).

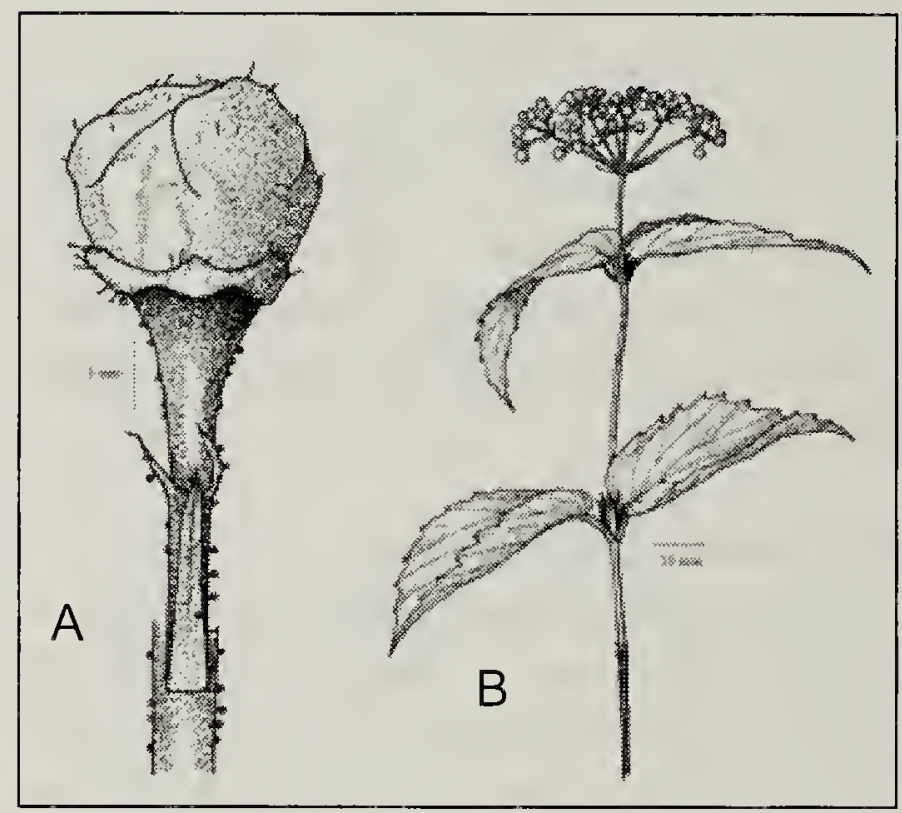

Figure 4. A) Pedicillate flower bud about to open, 30 May; B) twig with flower buds, 30 May

On 1 June, 18 (39\%) of 46 inflorescences had 1-9 open flowers. On 6 June, inflorescences were oval from above and averaged 4 (2.5-4.6) $\mathrm{cm}$ long by $3.5(2.3-4.5) \mathrm{cm}$ wide $(n=12)$. The long axis of the oval was parallel to the midribs of the opposite leaves at the base of the peduncle. On 8 June, about $95 \%$ of blooming was over and most corollas had fallen. Blooming lasted ca. 14 days from 27 May to 9 June.

\section{Flowers}

Flowers (Fig. 5) were perfect, white, hairless, odorless, and mostly pedicellate, although a few were sessile. They were $7-8 \mathrm{~mm}$ long (base of ovary to tip of anthers) by $6-7.3 \mathrm{~mm}$ 
wide. A flattened corolla was $3-3.7 \mathrm{~mm}$ long. The single, included pistil was ca. $3.5 \mathrm{~mm}$ long. After anthesis, the corolla fell, exposing the calyx lobes at the tip of the fertilized, expanding ovary. The style had a round base 1.3-1.5 $\mathrm{mm}$ wide and was tapered to the pale, greenish-tan, flat, lobed, stigmatic tip that was $0.6 \mathrm{~mm}$ wide. The stigma quickly turned dark brown after anthesis.

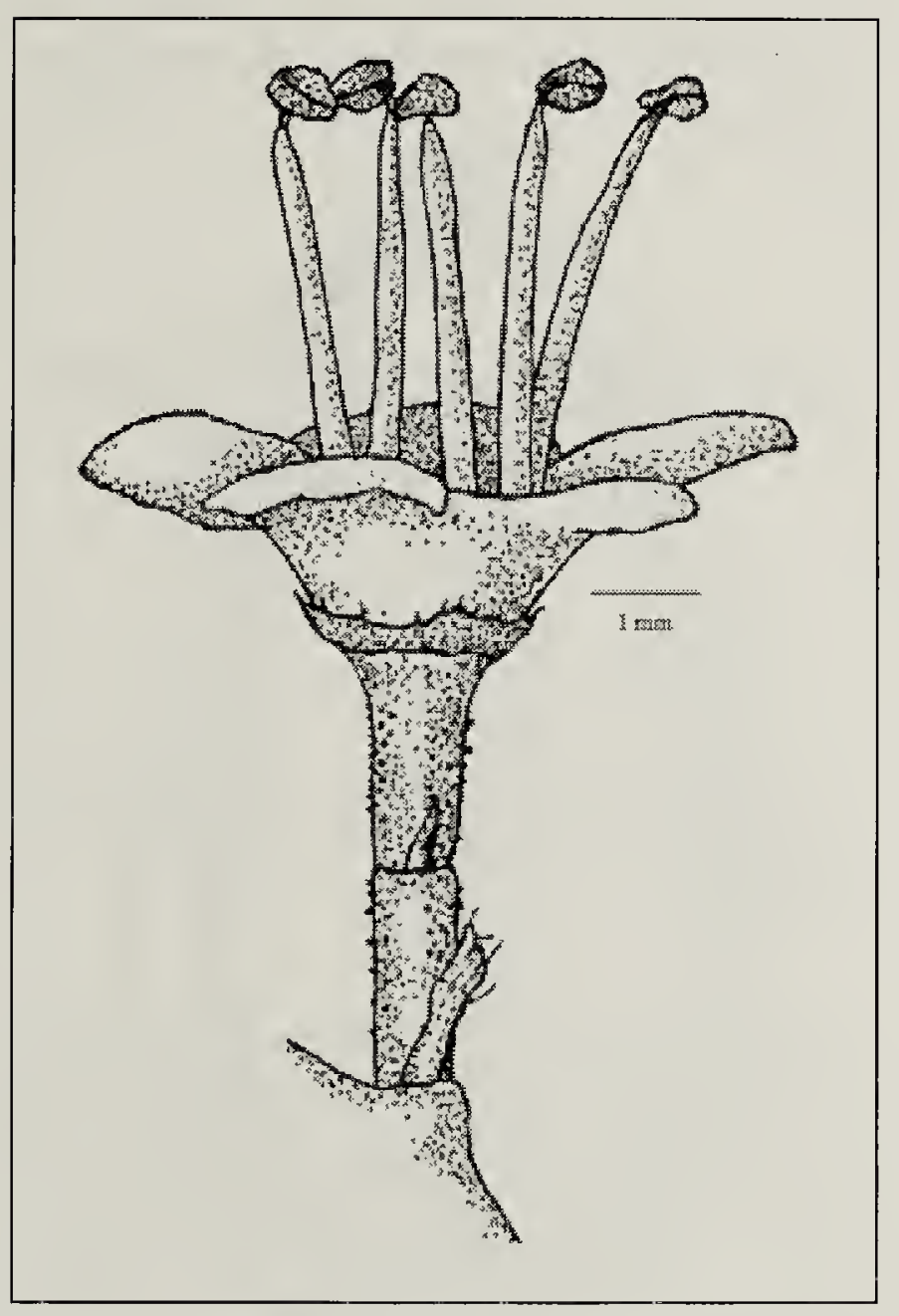

Figure 5. Open flower, 2 June

Subtending bracts of pedicels were 2-3.2 $\mathrm{mm}$ long by $0.3-0.6 \mathrm{~mm}$ wide, longer to shorter than the pedicel, entire, and hairy. Pedicels were $2.8(0-$ 7) $\mathrm{mm}$ long by ca. $0.5 \mathrm{~mm}$ thick and stipitate-glandular.

Subtending bracts of the ovary were paired, 0.5-0.7 mm long, entire, and tapered to a fine point. The ovary was $1-1.5 \mathrm{~mm}$ long by $0.8-1.2 \mathrm{~mm}$ wide, green, shiny with long green ridges and stipitate-glandular. Some young ovaries appeared frosty from numerous stipitate glands; others were almost eglandular. Glands were round, initially white, but quickly turned dark red and persisted on the expanding ovary.

Stamens (Fig. 6) numbered five and were exserted, hairless, attached to the base of the corolla tube, and dropping with it. Filaments were pale green in bud, becoming white, straight and tapered to the apices once the corolla opened. In flower, they were $3.5-5 \mathrm{~mm}$ long by ca. $0.4 \mathrm{~mm}$ wide with their bases ca. $0.5 \mathrm{~mm}$ apart. The filaments split apically, with each branch attached to a half-anther. Anthers were pale yellow and inverted in bud. In flowers, they were 1.2-1.4 mm long by ca. $1 \mathrm{~mm}$ wide. Spent anthers were golden brown, ca. $0.6 \mathrm{~mm}$ long and wide.

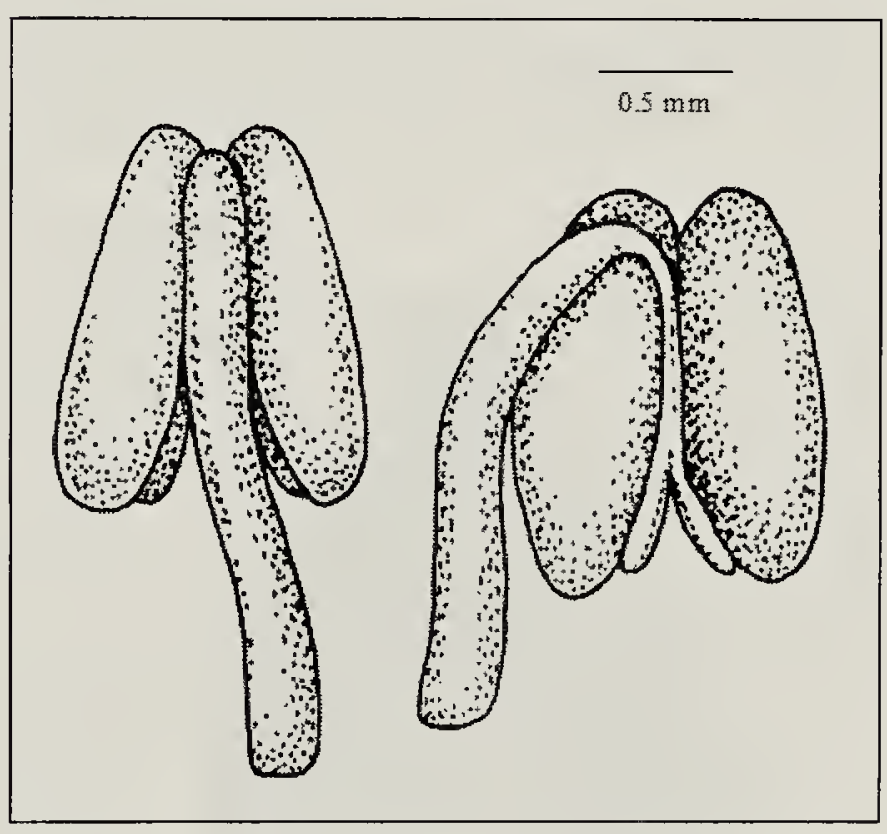

Figure 6. Stamens from a mature flower bud, 30 May

The calyx was tubular, five-lobed, and ca. $0.8 \mathrm{~mm}$ long by ca. $2 \mathrm{~mm}$ wide. The tube was $0.1-0.3 \mathrm{~mm}$ long; lobes were erose, $0.2-0.5 \mathrm{~mm}$ long by $0.6-$ $1 \mathrm{~mm}$ wide, and slightly ciliate with simple hairs ca. $0.2 \mathrm{~mm}$ long. Green at first, the calyx quickly turned wine red after the corolla fell.

The corolla was tubular and fivelobed. In bud, the outer corolla lobes were pinkish green and wrinkled, and 
gave the buds a bumpy appearance. The exposed lobes were adorned with a few scattered hairs and stipitate glands. The tube was $1.3-1.5 \mathrm{~mm}$ long with a circular basal opening 1.2$1.4 \mathrm{~mm}$ wide with a slightly erose edge. Lobes were round and 1.7-3 $\mathrm{mm}$ long by $2.2-3.8 \mathrm{~mm}$ wide.

\section{Fruit}

A one-stoned drupe developed from the single ovary in each flower. It enlarged quickly in June and was black and ripe by early August. Drupes were shiny, oval, and with dark reddish stipitate glands mostly at the two ends. Most drupes were ascending to spreading; some were drooping at the ends of rays.

On 5 April, I picked 39 fruits that had overwintered. They averaged 8.7 (7.69.7) $\mathrm{mm}$ long by $5.2(4.1-6) \mathrm{mm}$ wide by $4(3-5) \mathrm{mm}$ thick, and were black,

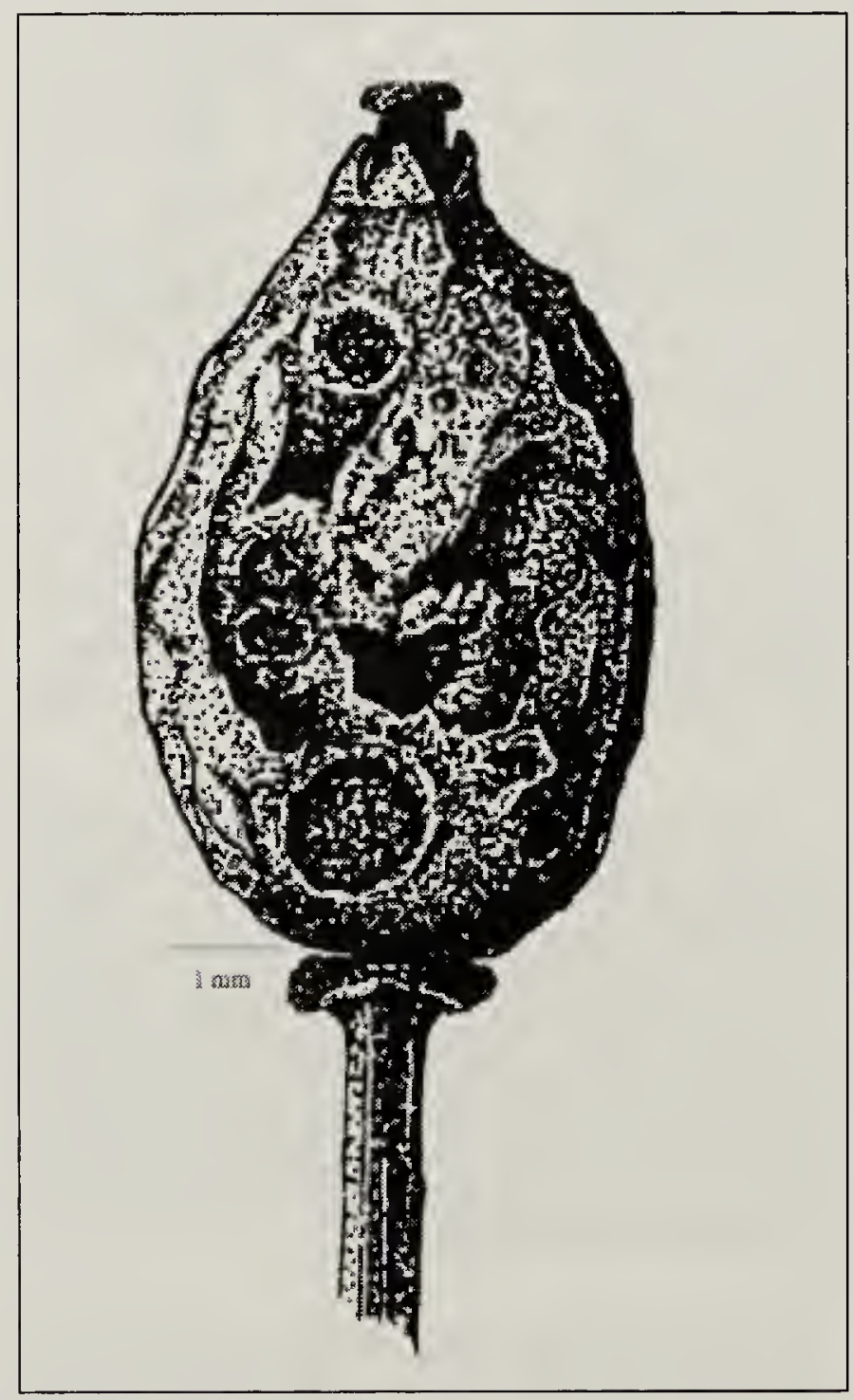

Figure 7. Overwintered fruit, 5 April wrinkled, dull, hard, and most contained a small hole from an insect (Fig. 7). At the apex, remnants of the style, stigma, and calyx formed a dark brown point $0.5-1.8 \mathrm{~mm}$ long.

On 23 June, the average number of green fruits per cluster was $5(0-17$; $\mathrm{n}=130$ ) compared to 47 flower buds on 1 June. On 18 August, the average cluster held 4 (1-14) fruits ( $n=200$; Fig. $8)$. Clusters without fruit were not included in the above count in August.

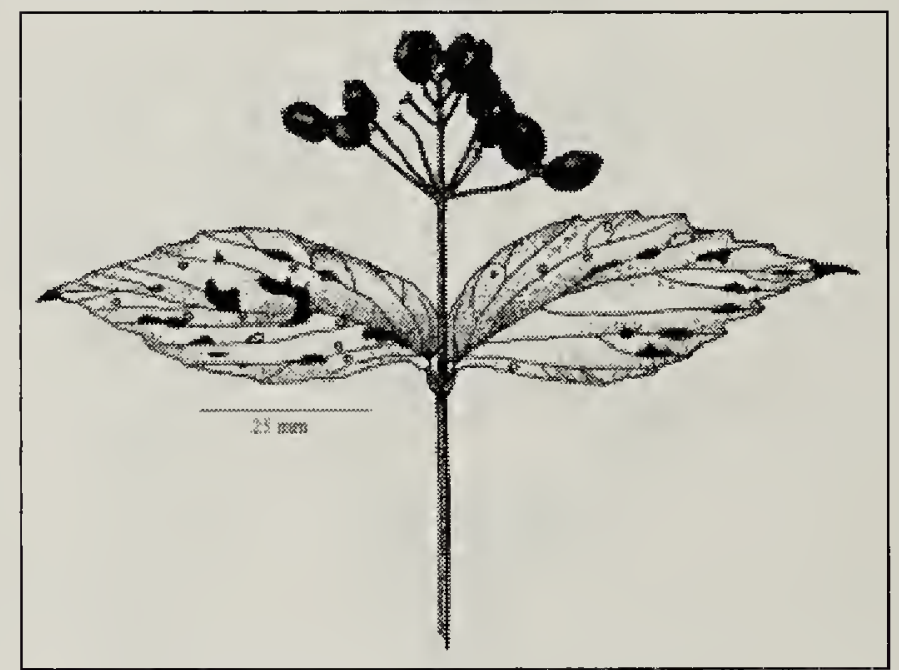

Figure 8. Cluster of ripe black fruit, 18 August

Ripe fruits on 22 September were on average $8.2(7-11) \mathrm{mm}$ long, 5.8 (5-6.7) $\mathrm{mm}$ wide, and $4.8(4.5-5) \mathrm{mm}$ thick ( $n=17$; Fig. 9). The outer black coat (exocarp) was $0.1 \mathrm{~mm}$ thick with a fleshy, golden-brown mesocarp inside around the stone.

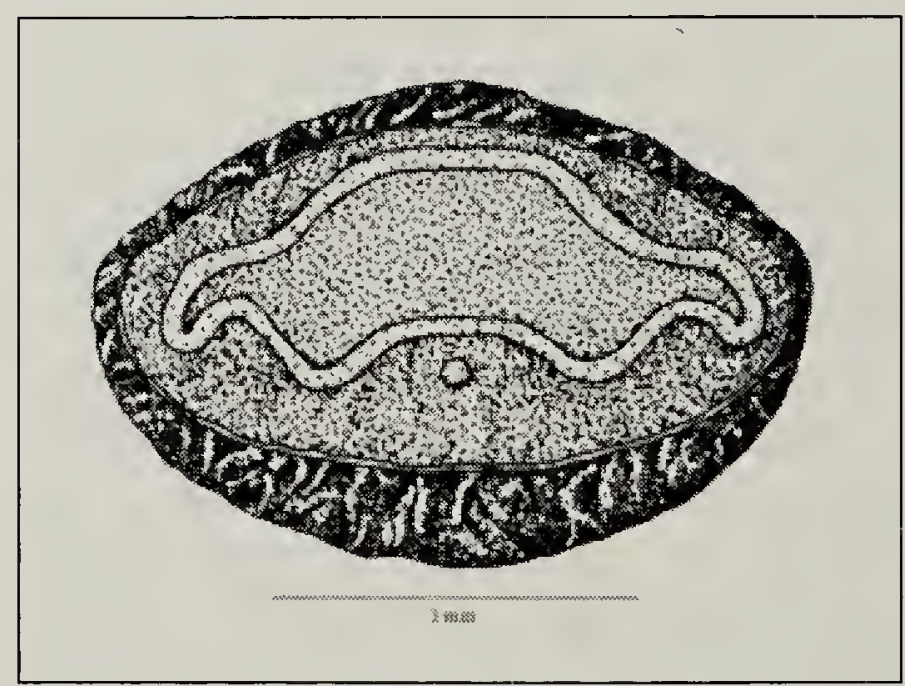

Figure 9. Cross-section of fruit showing stone and seed position and shape, 25 July 
In September, 22 ripe drupes were picked, and their stones (one per drupe) were removed and cleaned (Fig. 10). The stones averaged 7.2 (6.1-8.5) $\mathrm{mm}$ long by $4.4(4-5) \mathrm{mm}$ wide by $2.5(2.2-2.8) \mathrm{mm}$ thick, slightly rough, and tan to golden brown. One side was convex with two full-length wide shallow grooves. The other side had a deep narrow groove near each margin and a wide shallow groove in the middle over which extended the narrow round funiculus.

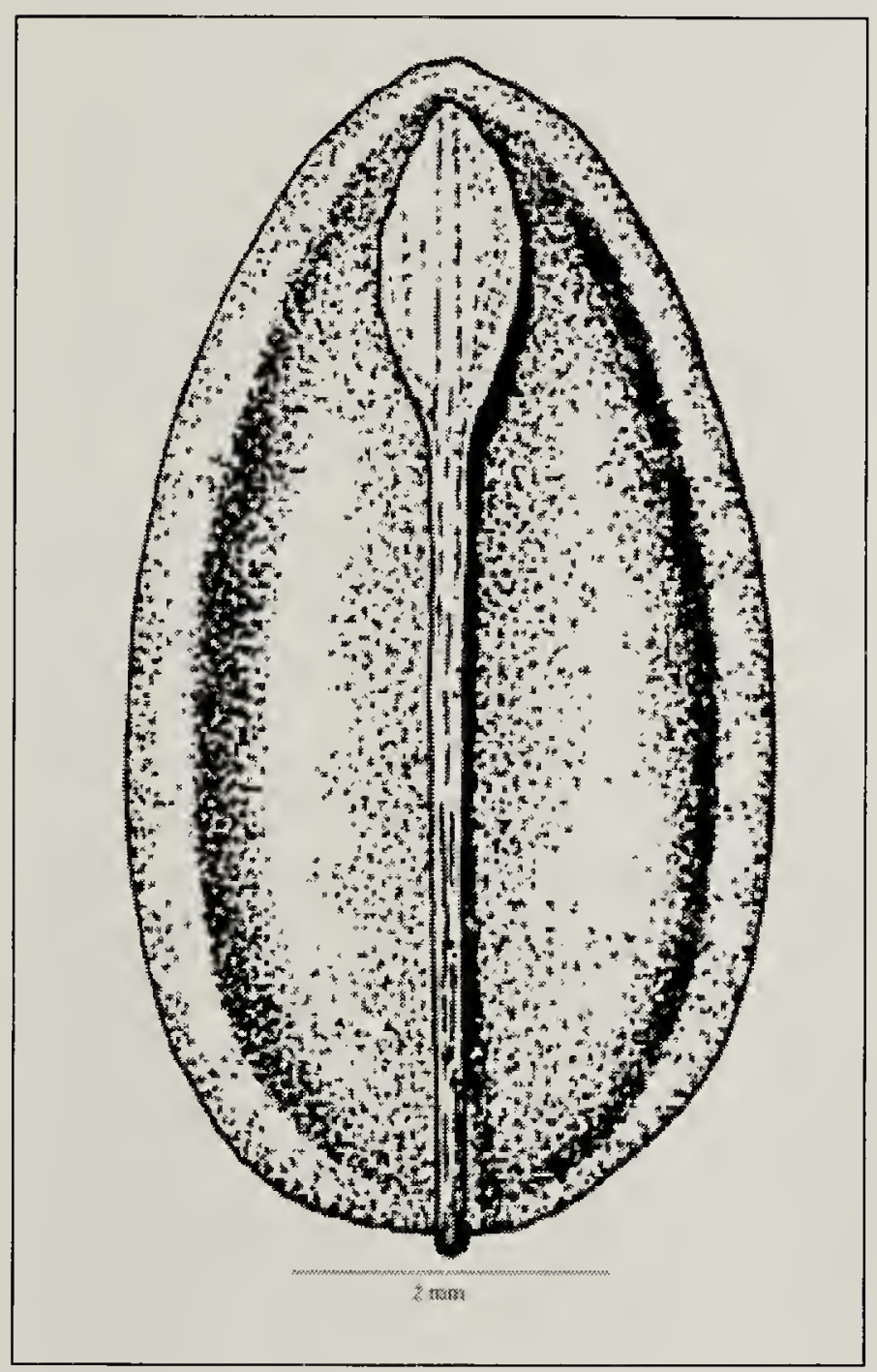

Figure 10. Stone from drupe, September

Damage from an unknown insect to the single seed inside each stone was common. For 22 stones, 17 (77\%) had one circular hole ca. $0.6 \mathrm{~mm}$ wide. Of the 17 stones, $11(65 \%)$ had a hole on the ventral side and $6(35 \%)$ had a hole on the convex dorsal side. Most of the holes were concentrated ventrally on either side of the funiculus near the end of a stone.

Phenology of fruit (2006): On 21 June, developing fruits were yellowish green and 7-8 $\mathrm{mm}$ long (including style and stigma) by $4-5 \mathrm{~mm}$ wide and 2.5-3 mm thick; on 25 July, most fruits were green but some had dark reddishbrown areas; on 3 August, most remaining fruits were black and slightly shiny; on 3 September, most fruits had fallen or had been eaten by birds, and the shrubs displayed empty rays.

\section{Seed}

The seed was difficult to remove intact from within the hard woody endocarp of the stone. Only two attempts were made to measure the seed from one large and one small ripe fruit. Seeds were $5.8-9.2 \mathrm{~mm}$ long by $4.2-4.8$ wide by $2-2.1 \mathrm{~mm}$ thick. A seed was light gray and firm.

\section{Wildlife Use}

No bird nests were built in arrowwood shrubs. White-tailed Deer browsed young twigs with flowers in bud or blooming and when fruits were green in early June. Usually both pairs of leaves along with flowers or fruit were eaten. A Red-eyed Vireo ate some black fruit on 19 August.

\section{Range}

In Canada, Downy Arrow-wood grows in Manitoba, Ontario and Quebec. It may eventually be found along the eastern border of southern Saskatchewan. It extends to the eastern seaboard and grows in 30 US states (AL, AR, CT, DE, GA, IA, IL, IN, $\mathrm{KY}, \mathrm{MA}, \mathrm{MD}, \mathrm{MI}, \mathrm{MN}, \mathrm{MO}, \mathrm{NC}, \mathrm{ND}, \mathrm{NH}$, NJ, NY, OH, OK, PA, SC, SD, TN, TX, $V A, V T, W I$, and $W V$ ). A range map of Downy Arrow-wood in Manitoba is shown in Fig. 11. 


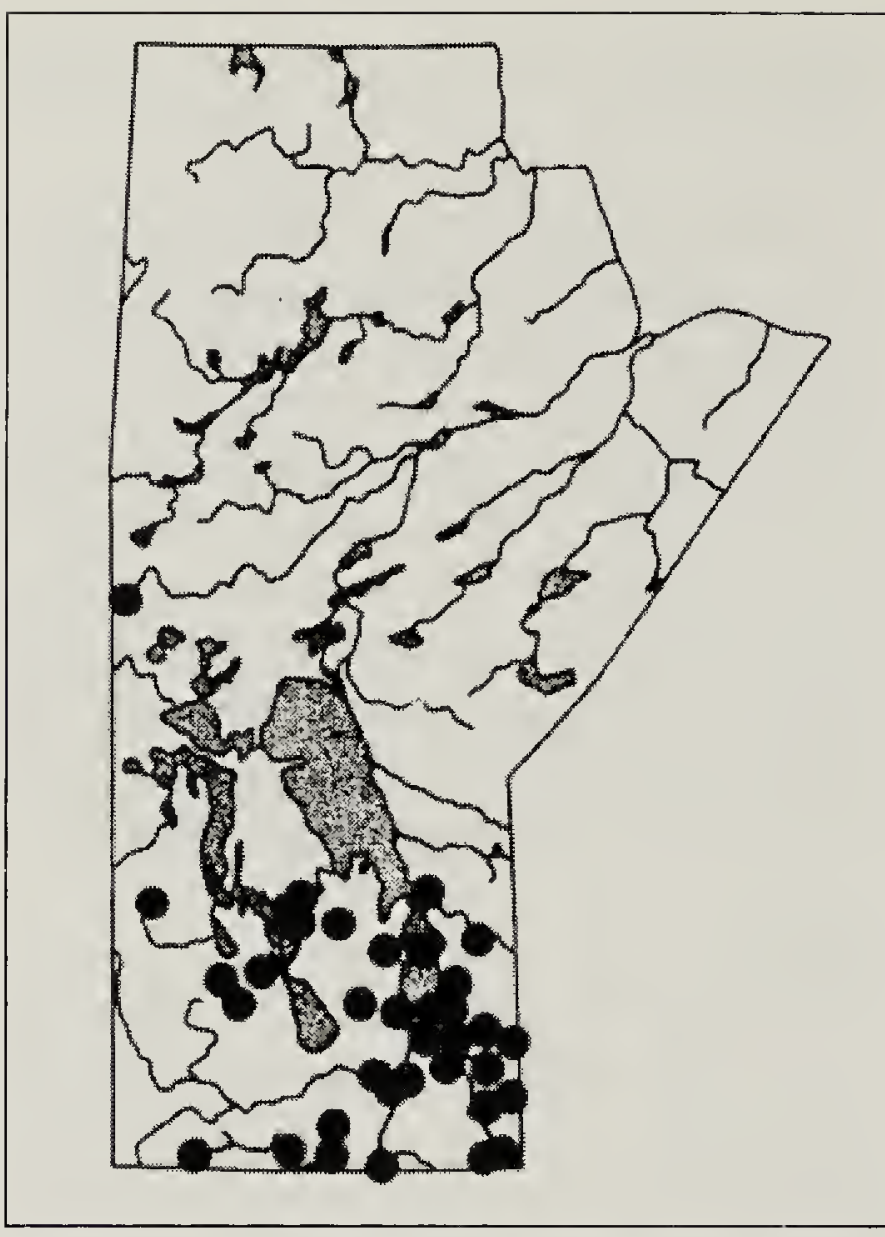

Figure 11. Dots show the distribution of Downy Arrow-wood in Manitoba

\section{Acknowledgements}

Diana Robson at The Manitoba Museum in Winnipeg provided access to a dot distribution map of Downy Arrow-wood in Manitoba. Anne Adkins, University of Winnipeg, provided a dissecting microscope.

NOTE: Tom Reaume's botanical book, 620 Wild Plants of North America, fully illustrated with ca. 5,000 ink drawings, is available from the Canadian Plains Research Center Press, University of Regina, SK, or your local bookstore.

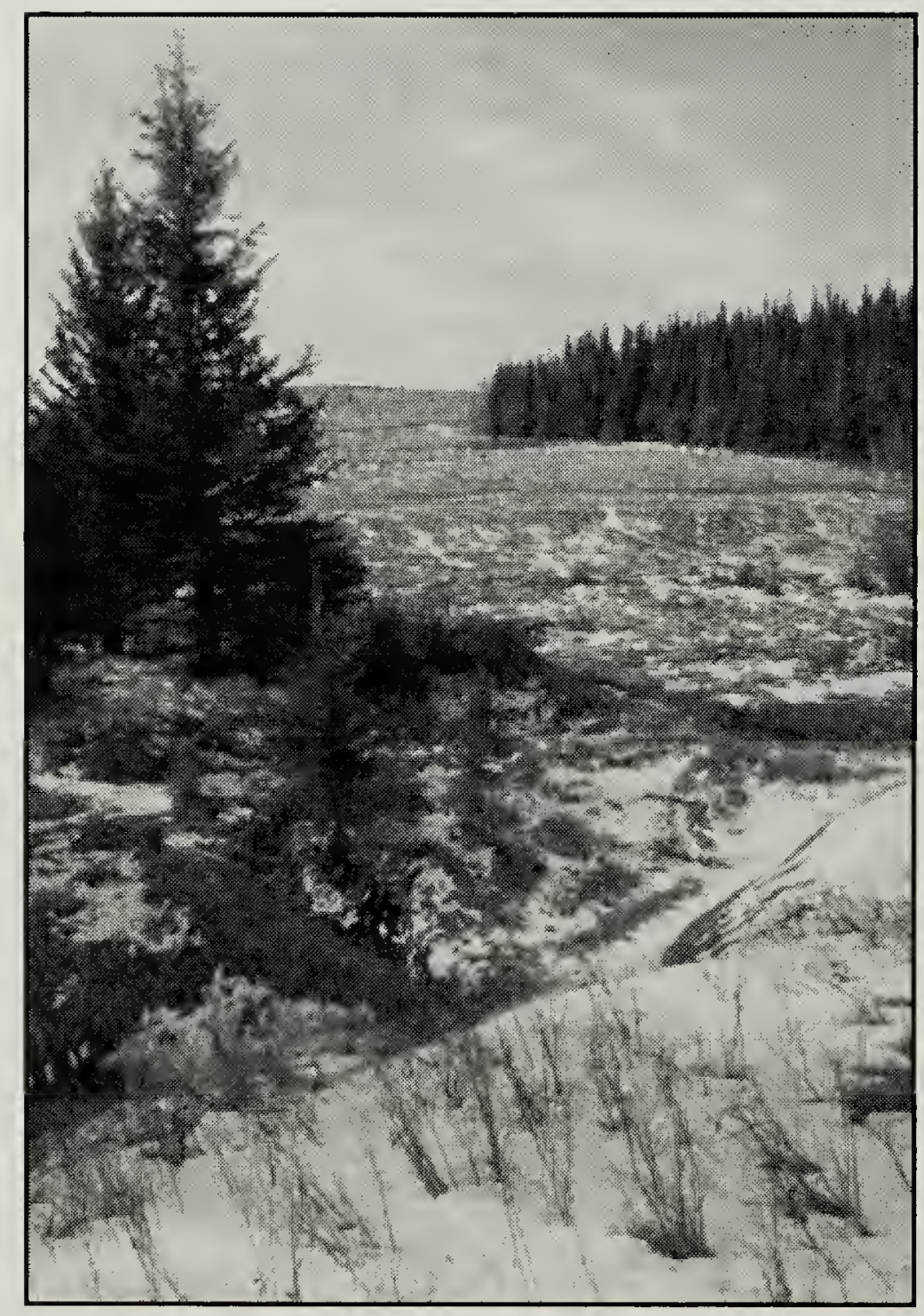

Remnants of an early June snowstorm in the West Block of Cypress Hills Interprovincial park. While we often think of climate change producing warmer and drier conditions in the prairies, more variable weather is another possible outcome. Nesting Western Bluebirds, Tree Swallows, and Sprague's Pipits likely had a hard time keeping their eggs warm during this cold wet period, while the bats that we were studying remained deep in torpor over a number of days.

- Mark Brigham, Department of Biology, University of Regina, Regina, SK; E-mail: <Mark.Brigham@uregina.ca> 